\title{
Increasing Students' Digital Literacy Utilizing Edublogs as a Learning Media
}

\author{
Sari Mubaroh ${ }^{1}$, Linda Fujiyanti ${ }^{2}$, and Muhammad Setya Pratama ${ }^{3}$ \\ ${ }^{1,2,3}$ Politeknik Manufaktur Negeri Bangka Belitung, Kawasan Industri Air Kantung, Sungailiat, Bangka Belitung, \\ Indonesia \\ ${ }^{1}$ sari@polman-babel.ac.id \\ ${ }^{2}$ linda@polman-babel.ac.id \\ ${ }^{3}$ msetyapratama@polman-babel.ac.id
}

\begin{abstract}
Most of SMA Negeri 1 Sungailiat students are less enthusiastic about school literacy because they feel bored when they have to read books. In addition, teachers are always the focus of learning makes it difficult for teachers to use literacy in the teaching and learning process. There's also another factor, it is the lack of optimization in the learning media used by the teachers because most teachers still only use books or lectures as learning media. Based on those factors, this study aims to see the increase in digital literacy of students through the use of edublogs. The research method used in this study was an experimental one-group pretest-posttest design. The sample in this study amounted to 35 students at SMAN 1 Sungailiat. This study uses data analysis through two stages, namely normality test and hypothesis testing. Researchers used the Shapiro Wilk test as the normality test. Then, hypothesis testing using the T-test 1 party using the paired sample t-test. The data processing uses SPSS 22. The results show that there are differences in values before and after treatment. The calculated $\mathrm{T}$ value obtained is -17.569 in the degree of freedom (df) or degrees of freedom showing the number 34 with a sig ( 2 tailed) value of 0.000 where this value is smaller than the critical limit of 0.05 . It means that the use of edublogs as a learning media could increase students' digital literacy.
\end{abstract}

Keywords: digital literacy, learning media, education.

\section{INTRODUCTION}

Based on the Regulation of the Education and Culture Minister, Number 23, 2015, it is mandatory for all functionaries in the education sector, from students, teachers, and education personnel to carry out the School Literacy Movement program. The existence of this regulation requires the implementation of the literacy movement in all subjects, not only Indonesian. At the start of the school literacy movement, students were required to read books and then rewrite or retell them. At the same time, the rapid development of students and their dependence on the digital world makes it more comfortable for them to be able to read and write online on their mobile devices.

Moreover, in today's digital era, students feel challenged to access, select and use information, and to track the information required by the accuracy and quality of the intervened information. Currently, this skill is known as literacy. Not only literacy but literacy is also an individual's ability to use all life skills and abilities. This justifies the need for a digital literacy program. Digital literacy programs are needed to identify users to be able to find the information they need, strategies to trace relevant information sources, weigh, use and disseminate it correctly. Among the 
many sites on the internet, blogs are one of the most visited digital literacy sites.

Blogs are websites that are often used to convey the desires of all disciplines, including education. Educational blogs are often called Edublogs [1] (Education blogs). Edublogs have the ability to support the education and learning process. For this reason, apart from being a medium or means of literacy, edublog can also be used as a learning media in teaching and learning activities. By implementing edublogs in learning activities, it is hoped that teachers can easily guide their students.

In an initial interview conducted at SMA Negeri 1 Sungailiat, it was shown that students were less enthusiastic about school literacy, because students felt bored when they were required to read books. In addition, the fact that teachers are always the focus of learning makes it difficult for teachers to use literacy movements in the teaching and learning process because the direct learning process is always teacher-centered. There are other factors, namely the lack of optimization in the learning media used by the teachers because most teachers still and only use books and PowerPoints as learning media. Based on the above factors, this has an impact on students' final grades.

Referring to the importance of using information technology in learning and digital literacy in education, especially secondary education, several studies have been carried out. Hernani \& Ahmad [2] concluded that the process skills of grade VII junior high school students improved after using digital literacy-based learning. Haristy, Enawaty, \& Lestari [3] concluded that there are differences in learning outcomes between students who learn to use literacy-based learning compared to those who learn to use conventional learning. Husain [4] concluded that the use of information technology and technology as learning media increases the learning motivation of junior high school students.

Furthermore, Amalia [5] stated that the digital literacy level of state high school students in Yogyakarta is already at the advanced level. Or in other words, students in the Special Region of Yogyakarta are digitally literate very well. This means that students are proficient in using a variety of technological devices, both hardware technology devices and software technology. Their critical understanding of internet content is very good, namely being able to analyse, evaluate and synthesise content. Likewise, research conducted by Bella [6] revealed that $\mathrm{R}$ was 0.669 , which indicates that the relationship between the application of digital literacy (variable $\mathrm{X}$ ) and learning improvement (variable Y) is strong. Thus, it can be stated that the application of digital literacy has an influence on improving learning.
In terms of developing e-learning assisted learning methods, edublogs can be a learning medium. Sumbawati[7] states that students have a positive response to cooperative learning type think talk write using edublogs. Chairuddin [1] added in his research that edublogs media is very helpful for teachers in relation to using online-based media so that students feel happy and not boring. Besides, a study from Samani [8], edublogs provides insights to educators in improving their digital literacy in society, but also among students. Likewise, Hajar[7] in his article entitled "Think Talk Write with Edublogs as Digital Literacy for Students" concluded that students had a positive response to learning Think Talk Write with Edublogs.

Based on the description above, the description of literacy among students of SMA Negeri 1 Sungailiat is an interesting thing to study. This research is expected to be input for school administrators in order to design a media literacy education that can improve literacy skills and student learning outcomes. This research is entitled "Increasing Student Digital Literacy Through the Use of Edublogs as Learning Media."

\section{LITERATURE REVIEW}

\subsection{Digital Literacy}

Gilter explains that digital literacy is the ability to understand and use information in many formats from various sources when it is presented via a computer. Digital literacy, also known as computer literacy, is one of the components in media literacy skills, which is the skill of using computers, the Internet, telephones, PDAs, and other digital devices. Digital literacy refers to efforts to recognize, search for, understand, assess and analyse, and use digital technology.

Furthermore, Jones [9] defines digital literacy as an individual's interest, attitude and ability in using digital technology and communication tools to access, manage, integrate, analyse and evaluate information, build new knowledge, create and communicate with others in order to participate effectively in Public. Digital media is one of the gadgets in new media, in the book Communication and Commodification. The definition of new media explained that there are four main categories, namely (1) interpersonal communication media such as email. (2) Interactive game media such as games. (3) Information search media such as search engines. (4) Participatory media, such as chat rooms on the Net.

Based on some definitions of digital literacy above, the researchers concluded that digital literacy according to researchers is the individual's ability to use digital technology and understand, evaluate, criticize, analyse 
any information presented in various forms of digital format based on the era of its development.

\subsection{Edublogs}

Boas states that a blog which comes from the words web and log, is a personal journal or diary using webbased pages that allow writers to post various articles that can be seen and responded to by the world-wide audience. Asoodar, Atai, \& Vaezi say that blogs or also known as weblogs are internet-based media that replace conventional learning logs in language learning. Foster takes the view that blogs are online repositories of individual entries or "posts" that are usually displayed in reverse chronological order. They have facilitated the direct action of micro-publishing for hundreds of millions of people.

Meanwhile, Edublogs [1] (Education Blogs) according to Ririn [10] is a blog that is used for education. Edublogs can also be referred to as ELearning media because they can be used in distance learning. Edublogs also provide features that can be used to monitor students' personal blogs, so that it can be ensured that the articles on student blogs are educational and educational. Plus, edublogs is a free internet-based platform that provides users to post their ideas and thoughts in the form of a blog. Lukmana [11] states that there are several benefits of blogs when used in learning, namely:

- Facilitate communication between teachers and students, teacher and guardian, or teacher and teacher.

- Supports the growth of informative dialogue, through post and comment features

- Helping students to have space to express opinions without limits and can be used as space to develop personal desires.

- Blogs are a means for students to express ideas in informative writing.

Furthermore, Churchill states that blogs are starting to emerge as a useful type of educational technology. Some literature discusses a number of interesting possibilities for blog use. Many websites or platforms offer free web-based blogs on the internet that can be accessed by everyone such as Wordpress, Blogspot, Google Sites, and Edublogs. With this in mind, the authors took Edublogs as a medium. Edublogs[1] (2017) and Urbano \& Villanueva (2012) mention some of the features provided on Edublogs as follows: (1) Sharing material, news, downloads, links, and others. Teachers can share anything with the post on the blog, then instantly accessible to students from anywhere. (2) Facilitating online discussion and collaboration.
Students can easily respond to their teachers or friends' blog posts and discuss topics through comments. (3) Making class publications that can be easily published by students. (4) Get students to blog, so they can share their work and thoughts. (5) Obtaining feedback or gathering information.

\subsection{Learning Media}

Azhar[12] describes that in a teaching and learning process, two very important elements are teaching methods and learning media. These two aspects are interrelated. The choice of a particular teaching method will affect the appropriate type of learning media, although there are still various other aspects that must be considered in selecting media, including learning objectives, types of tasks and responses that students are expected to master after learning takes place, and learning context including student characteristics. Even so, it can be said that one of the functions of learning media is as a teaching aid that influences climatic conditions and the learning environment that is organized and created by the teacher. The word media comes from the Latin medius which literally means middle, intermediary or introduction.

From some of the above definitions, it can be concluded that learning media is everything both hardware (everything that can be heard, seen or touched with the senses) and software (the content to be conveyed) that can be used to convey messages / information from source to recipient and can be used en masse, large / small groups or individually in the learning process.

\section{RESEARCH METHODS}

This research was conducted at SMA Negeri 1 Sungailiat which is located at Jalan Pemuda, Sungailiat Regional Government Complex, Parit Padang, Sungailiat, Bangka Regency, Bangka Belitung Islands. And applied to class XII as a population and class XII MIPA 2 as a sample with a total of 35 students. The sample selection was not random due to requests from the school that the class that was ready to be used as the research sample was class XII MIPA 2.

In this study, using a Pre-Experimental Design with the type of One-Group Pretest-Posttest Design. The implementation of this study used an experimental group which at the beginning of the study was given a pretest which was useful for knowing the basic abilities of students before doing the treatment. After that the students were given treatment, namely learning using edublogs. After getting the treatment, a posttest will be carried out which aims to whether the treatment carried 
out in the teaching and learning process is successful which refers to the increase in students' digital literacy.

TABLE 1. Pre-experimental Design

\begin{tabular}{ccc}
\hline Pre-test & Treatment & Post-test \\
\hline O1 & & \\
(Pre-test & Habitual Literacy & O2 \\
value $)$ & utilising Edublogs & (Post-test \\
score)
\end{tabular}

(Sugiyono, 2009)

\subsection{Research Instruments}

The research instruments used in this study were module validation, questions and media. To obtain validation results, the data obtained will be interpreted with the following interpretation table:

TABLE 2. Interpretation of the Validation Score

\begin{tabular}{cc}
\hline Percentage & Criteria \\
\hline $0 \%-20 \%$ & Invalid \\
$21 \%-40 \%$ & Less Valid \\
$41 \%-60 \%$ & Quite Valid \\
$61 \%-80 \%$ & Valid \\
$81 \%-100 \%$ & Very Valid \\
\hline & (Riduwan, 2015)
\end{tabular}

\subsection{Data analysis}

This study uses data analysis through two stages, namely normality test and hypothesis testing. The normality test of researchers used the Shapiro Wilk test. After testing, if the data is normal, it will continue to test the hypothesis. Hypothesis testing using the T test 1 party using the paire sample t-test. The data processing uses SPSS.

\section{RESULTS AND DISCUSSION}

\subsection{Validation Results}

Data validation results were obtained from three validators, namely two lecturers from the Department of
Electrical Engineering and Informatics at Polman Babel and one teacher from SMA Negeri 1 Sungailiat. The three validators were given research instruments along with a validation assessment questionnaire. After the assessment process by the validator, the researcher performs calculations according to the specified formula. Then the results obtained by the module device get a percentage of $90 \%$, the item set gets $87 \%$, and the learning media gets $91 \%$. The five validated learning instruments fall into the very feasible category. The validation results are depicted in the form of a bar chart as below:

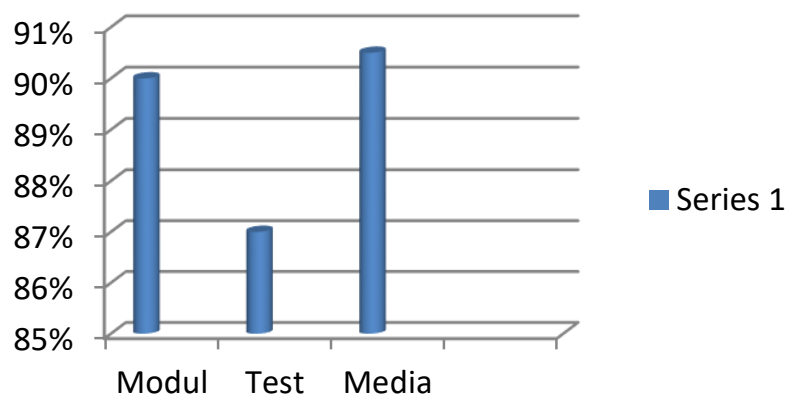

FIGURE 1. Validation of Research Instruments

\subsection{Normality test}

According to the research design, students are given a pretest and posttest. After obtaining the pretest and posttest values, the next step is to do the normality test. The normality test is used to determine whether the data obtained is normally distributed or not. The normality test used by the author is the Shapiro Wilk test, this is an adaptation and development of the Komogorov-Smirnov test. The normality test has two assumptions, namely:

Ho : Samples are normally distributed

H1 : Samples are not normally distributed

With the test criteria $\mathrm{H} 0$ accepted if the level of significance $<0.05$ while $\mathrm{H} 1$ accepted if the significance level $>0.05$. The following are the results of the normality test from the data obtained.

Tests of Normality

\begin{tabular}{|l|r|r|r|r|r|r|}
\hline & \multicolumn{4}{|c|}{ Kolmogorov-Smirnova } & \multicolumn{3}{|c|}{ Shapiro-Wilk } \\
\cline { 2 - 7 } & Statistics & Df & Sig. & Statistics & \multicolumn{1}{c|}{ Df } & \multicolumn{1}{c|}{ Sig. } \\
\hline pre test &, 118 & 35 &, $200 *$ &, 945 & 35 &, 080 \\
posttest &, 140 & 35 &, 082 &, 911 & 35 &, 008 \\
\hline
\end{tabular}

*. This is a lower bound of the true significance.

a. Lilliefors Significance Correction

FIGURE 2. Pretest Posttest Normality Test 
The significance value in the pretest normality test is 0.080 where the value is greater (>) than the significance value of 0.05 so it can be interpreted that the pretest value data in the experimental class is data that is normally distributed. The significance value in the posttest normality test is 0.08 where the value is greater $(>)$ than the significance value of 0.05 so that it can be interpreted that the posttest value data in the experimental class is data that is normally distributed.

\subsection{Hypothesis Testing}

After carrying out the normality test and the results obtained that the data has a normal distribution. Then it can be done to the next stage, namely hypothesis testing. Hypothesis testing using paired sample T-Test. With the following hypothesis:

$\mathrm{H}_{0}$ : There is no increase in students' digital literacy between before and after utilising the edublogs as a learning media

$\mathrm{H}_{1}$ : There is an increase in students' digital literacy between before and after utilising edublogs as a learning media

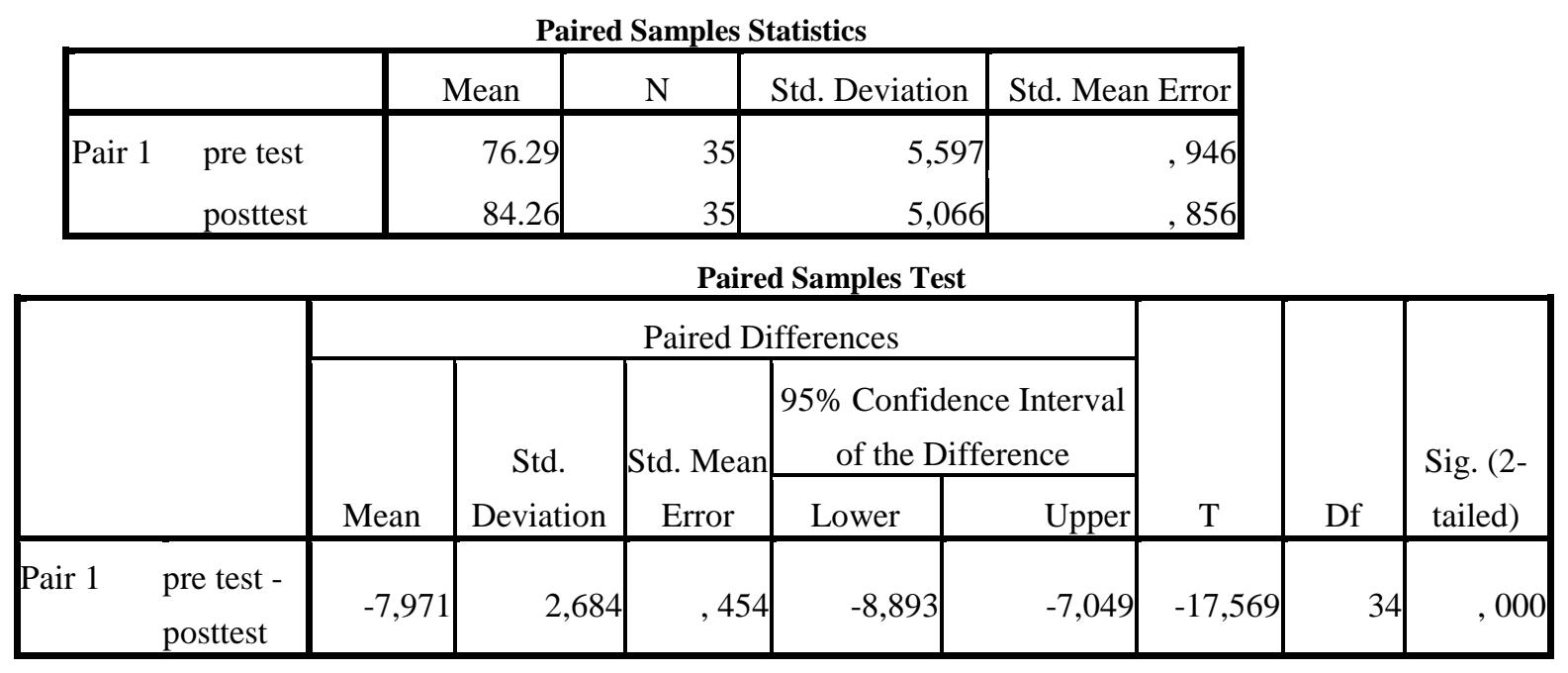

FIGURE 3. Hypothesis testing

Hypothesis test results in the table above obtained an average pretest value of 76.29 , while the average posttest value is 84.26 with a standard deviation of 5.066. Based on the average results of the pretest and posttest, it shows that there are differences in values before and after treatment. The calculated $\mathrm{T}$ value obtained is -17.569 in the degree of freedom (df) or degrees of freedom showing the number 34 with a sig $(2$ tailed) value of 0.000 where this value is smaller than the critical limit of 0.05 The criteria for testing the hypothesis probability $<0.05$, it can be concluded that the hypothesis test accepts $\mathrm{H} 1$ and rejects $\mathrm{H} 0$ or which means that there is an increase in students' digital literacy competencies between before and after using edublogs learning media.

\section{CONCLUSION}

Based on the results of data analysis, it can be concluded:

- Hypothesis test results The calculated $\mathrm{T}$ value obtained is -17.569 in the degree of freedom (df) or degrees of freedom showing the number 34 with a sig ( 2 tailed) value of 0.000 where this value is smaller than the critical limit of 0.05 . In accordance with the probability hypothesis testing criteria $<0.05$, it is concluded that the hypothesis test accepts $\mathrm{H} 1$ and rejects $\mathrm{H} 0$, which means there is an increase in students' digital literacy between before and after using edublogs learning media.

- Edublogs learning media in literacy digital activity at SMA Negeri 1 Sungailiat is declared very valid with a total value given by the two validators of $91 \%$. The validators who gave the assessment were 1 lecturer in the Department of Electrical Engineering and Informatics and 1 teacher at SMA Negeri 1 Sungailiat.

- The results of students' digital literacy show that all can use edublogs using the comments column to interact with the teacher. 


\section{ACKNOWLEDGMENTS}

The author would like to thank the Director of the Bangka Belitung State Manufacturing Polytechnic who has helped in funding so that Research with the title of "Increasing Students' Digital Literacy Utilising Edublogs as A Learning Media" can run smoothly.

\section{REFERENCES}

[1] "E-Learning (Edublogs) Social Media Based: its implementation in teaching learning at Islamic Senior High School Bangkalan, Chairuddin, Jurnal Pengabdian Masyarakat Khatulistiwa." http://jurnal.stkippersada.ac.id/jurnal/index.php/JP MK/article/view/543 (accessed Jan. 24, 2021).

[2] H. Hernani and A. Mudzakir, "Pengaruh Pembelajaran Berbasis Literasi Sains dan Teknologi Terhadap Keterampilan Proses Sains Siswa SMP," J. Pendidik. Mat. Dan Sains, vol. 15, no. 1, Art. no. 1, 2010, doi: 10.21831/jpms.v15i1.12195.

[3] D. R. Haristy, E. Enawaty, and I. Lestari, "Pembelajaran Berbasis Literasi Sains Pada Materi Larutan Elektrolit Dan Non Elektrolit Di Sma Negeri 1 Pontianak," J. Pendidik. Dan Pembelajaran Khatulistiwa, vol. 2, no. 12, Art. no. 12, Dec. 2013, Accessed: Jan. 24, 2021. [Online]. Available: https://jurnal.untan.ac.id/index.php/jpdpb/article/v iew/4002.

[4] Husain, C, "Pemanfaatan teknologi informasi dan komunikasi dalam pembelajaran di SMA Muhammadiyah Tarakan.," J. Kebijak. Dan Pengemb. Pendidik., vol. 2, no. 2, 2014.

[5] R. R. Amalia, "Literasi Digital Pelajar SMA : Kemampuan Berkomunikasi dan Berpartisipasi Pelajar SMA Negeri di Daerah Istimewa Yogyakarta Melalui Internet," J. Studi Pemuda, vol. 4, no. 1, Art. no. 1, Jul. 2018, doi: 10.22146/studipemudaugm.36733.

[6] 531303242 Bella Elpira, "Pengaruh Penerapan Literasi Digital terhadap Peningkatan Pembelajaran Siswa di SMP Negeri 6 Banda Aceh," skripsi, UIN Ar-Raniry Banda Aceh, 2018.

[7] M. S. Sumbawati and H. N. Artika, "Penerapan Metode Pembelajaran Kooperatif Tipe Think Talk Write Berbantuan Edublogs," J. Vocat. Tech. Educ. JVTE, vol. 1, no. 2, Art. no. 2, Oct. 2019.

[8] E. Samani, R. Bagheripour, and N. Noordin, "Effect of a Course on Educational Tools on Students' Attitude and Digital Literacy Skills,"
Int. J. Educ. Technol. Learn., vol. 8, no. 1, Art. no. 1, Apr. 2020, doi: 10.20448/2003.81.38.46.

[9] Jones, Rodney H \& Hafner, Christoph A, Understanding Digital Literacies: A Practical Introduction. New York: Routledge, 2012.

[10] Sjariani, Ririn, Web 2.0: Panduan Bagi Para Pendidik. Jakarta: PT Indeks, 2011.

[11] Lukmana, L, Guru Go Blog. Yogyakarta: CV Andi Offset, 2013.

[12] Arsyad, Azhar, Media Pembelajaran. Jakarta: PT Raja Grafindo Persada, 2005. 